\title{
歯内治療におけるレーザーの位置づけ：基礎と実際
}

庄司茂

\author{
東北大学大学院歯学研究科歯内歯周治療学分野
}

(受付： 2009 年 7 月 31 日, 受理 : 2009 年 8 月 31 日)

\section{Significance of Laser on the Endodntic Treatment}

\author{
Shigeru SHOJI \\ Department of Periodontics and Endodntics, Tohoku University \\ Graduate School of Dentistry
}

(Received: July 31, 2009, Accepted for Publication: August 31, 2009)

\begin{abstract}
In the application of laser to the area of endodntics, we have the problem that the object of laser treatment is narrow area. Especially to treat a root canal, we have the difficulties on both the guide of laser beam and the irradiating direction of laser. Moreover during the irradiation of laser beam at an apical area, if we applied the laser beam to the apical tissue through the apical foramen, the apical tissue was wounded. Then the patient will feel the pain. Although the laser treatment has these problems on the area of endodntics, we will get the development on the promotion of care and the establishment of painless treatment. But if we can't exhibit the cause of disease, we should not do the aimless laser irradiation to avoid the spreading of pain.
\end{abstract}

(J. Jpn. Soc. Laser Dent. $20: 130 \sim 134,2009$ Reprint requests to Dr. SHOJI)

Key words = Significance, Laser, Endodntic treatment

キーワード＝重要性，レーザー，歯内治療

\section{はじめに}

歯内治療において, 多種類のレーザーが研究されてきて いるものの，まだ，第一選択の治療法としては認められて いない。しかし，今後の発展の可能性は充分に考えられ る。ただし，歯内治療領域でレーザー照射を行う場合に は，根管という狭い空間での象牙質や歯髄組織さらには根 尖部歯周組織という異なる構成体を踏まえて，治療に当た る必要がある。

このような, 他の部位でのレーザー照射とは異なる条件 を踏まえて, 歯内治療でのレーザーの位置づけを考えてみ る。

I 、レーザー治療の基礎

1. 日本で用いられているレーザー装置

現在, 日本で厚生労働省から正式の認可を得ているもの は 5 種類のレーザーである。それぞれのレーザーは波長が
異なっているので, 歯内治療への応用に当たっては, 対象 が歯䯣という軟組織であるのか, 象牙質という硬組織であ るかということへの充分な配慮が必要である。特に, 厚生 労働省認可の無いレーザーを使用する場合は, 術者として の責任範囲がどこまで及ぶのかをはっきりと認識して用い るべきである。

2. レーザー照射による軟組織での反応

レーザーの波長によっては表層で蒸散や炭化が起きず, 浮腫が生じる場合があるが，基本的には，まず表層組織の 「蒸散」, ついで「炭化層」, その下に「熱凝固層」と「熱 変性層」が生じる。歯内治療での対象軟組織である歯䯣や 根尖部歯周組織でも, 同じ反応が生じることを念頭にレー ザー照射することが大切である。

3. 歯髄に対する高周波治療器 (電気メス) との相違 レーザーと類似の作用を持つ電気メスと比較してみる と, 我々が歯科治療で用いている電気メスは単極なので, 


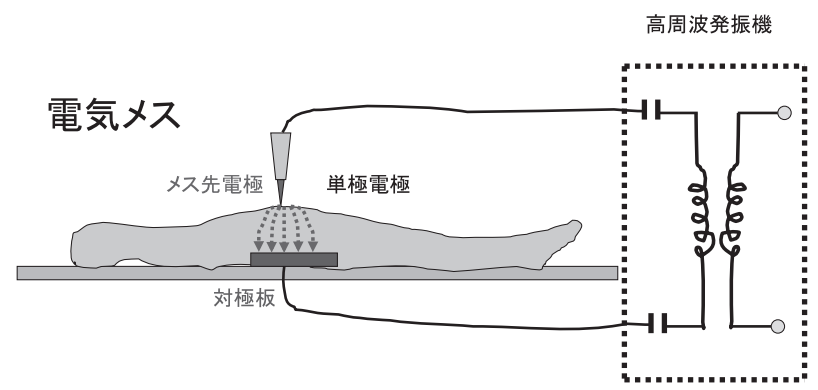

高周波電流回路

図 1 高周波治療器の生体への応用

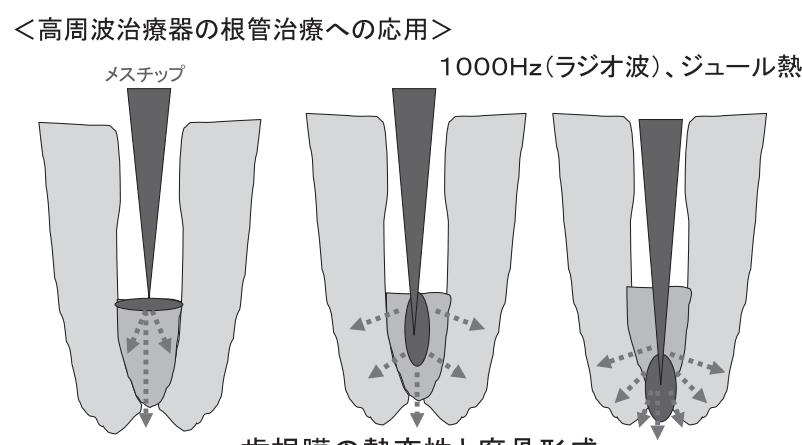

歯根膜の熱変性と腐骨形成

図 2 歯髄処置としての外科的ジアテルミー

電気エネルギーが金属チップ先端に集中した熱エネルギー に変化する（図 1)。この電気入久を根管内歯髄に作用さ せた場合, チップの位置により歯䯣組織は変性する（図 2)。この場合に注意が必要なのは, 根管内での過剩蓄熱と 根尖孔外一の漏電による歯根膜の熱変性抢よび腐骨形成で ある。一方，レーザーではその波長の違いにより，反応が 異なる（図 3)。

つまり, レーザーとの最大の違いは, レーザー光は光が 到達しなければ, それ以上, 深部への波及は生じないのに 対し, 電機メスでは電源を ONにしている限り, 常に電気 エネルギーとして生体内深部一と流れ続け熱的影響を及ぼ すことである。可能な限り根尖孔外歯周組織への影響を防 止する事が，痛み発現防止に繋がるので重要である。

4. レーザー照射による硬組織での反応

象牙質の方がエナメル質よりも吸収性が高いので，現在 臨床で用いられているレーザーでの根管拡大を考えた場 合，Er:YAGレーザーの使用が考えられる。

II． 歯内治療へのレーザー応用の実際

1. 根管内象牙質への照射（根管拡大・形成）

髄腔開拡後に根管口を経由して, 根管内象牙質にレー ザーを照射しょうとした際に，どうしても目的とする根管 側壁の象牙質ではなく根尖孔に向かってレーザー光線が照 射されてしまう（図 4a)。この問題を解決するために,

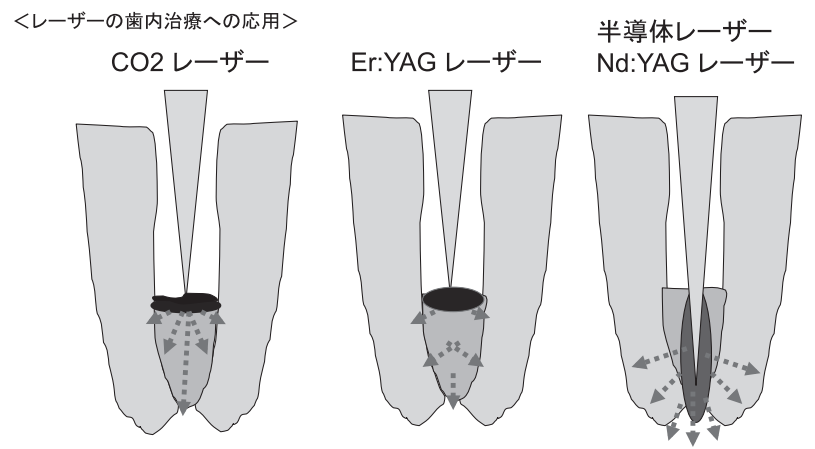

歯根膜の熱変性と腐骨形成の危険性を考えるべき

図 3 根管処置としてのレーザー照射（歯髄除去）

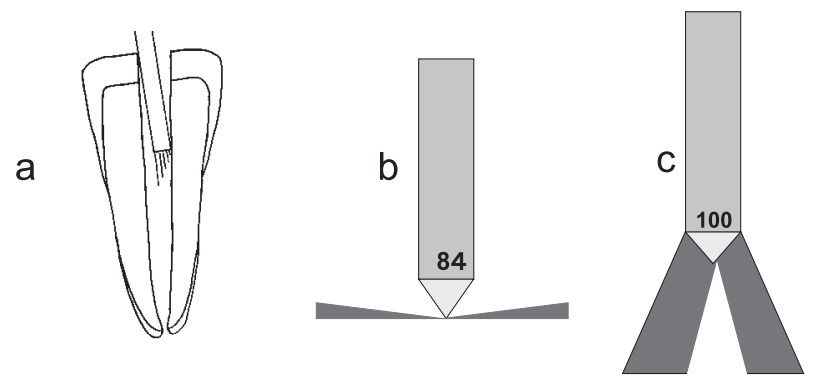

図 4 根管内象牙質照射におけるレーザー照射方向

我々は Er:YAG レーザー導光用チップの先端角度を変え ることにより根管側壁象牙質 (図 $4 \mathrm{~b}$ : 先端角度 84 度 $)^{1)}$ あるいは側枝（図 $4 \mathrm{c}$ ：先端角度 100 度）に向けての選択 的照射が可能であることを明らかにした。多くの種類の照 射用チップ先端角度を有効に用いることが，今後の治療成 功につながると考えられる。

特に, Er:YAG レーザー照射により拡大された象牙質表 面にはスメア層が形成されないことは，今後のレーザー根 管拡大への大きな可能性と考えている。

2. レーザー照射による殺菌効果

Er:YAG レーザーは水酸基への吸収が大きいので, 細菌 類に対しても硬組織と同様に破壊的に働くと考えられる。 そこで, 牛象牙質に人工感染根管 $(0.5 \times 5 \mathrm{~mm})$ を作製 し，その根管内に細菌（Str.sanguis）を播種後 24 時間培 養し，人工罹患根管を作成した。

根管内を生理食塩水で洗浄後ペーパーポイントで清拭 し, 直径 $200 \mu \mathrm{m}$, 先端角度 84 度のチップを用い, 出力 $4 \mathrm{~mJ}$ と $8 \mathrm{~mJ}$ で，引き上げながら Er:YAG レーザーを照射 した（図 5)。照射後，市販のステンレスドリル（直径： $0.52 \sim 0.80 \mu \mathrm{m})$ で根管拡大し，得られた削片をプラディ ア昭和（昭和薬品化工）で培養し, 細菌の増殖を判定した (図 6)。その結果，ある梁さまではレーザーによる殺菌が 可能であることが判明した（表 1)。つまり，次亜塩素酸 


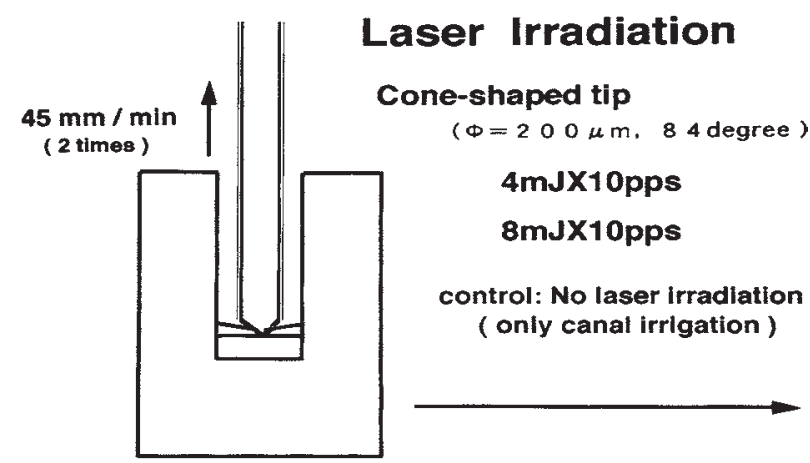

図 5 人工感染根管内でのレーザー照射（チップ先端角度：84 度）

\section{Bacteriological examination (2)}

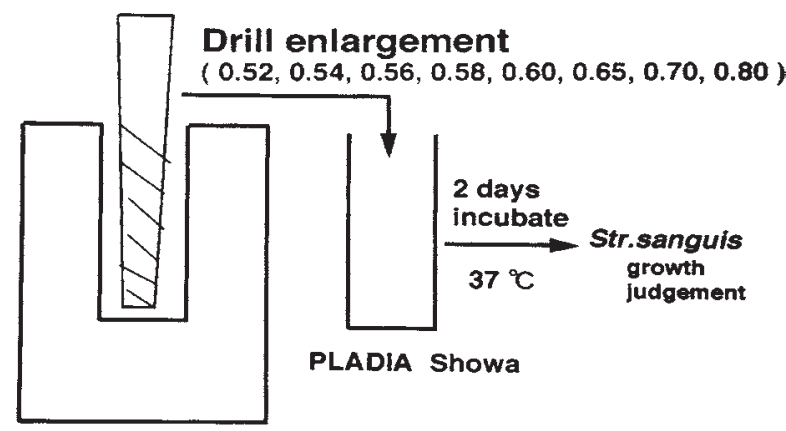

図 6 ドリルを用いた根管内象牙質採取と細菌培養

表 1 レーザー照射後の Str.sanguis 培養結果

$<$ Er:YAG laser irradiation $>8 \mathrm{~mJ} \times 10 \mathrm{pps}$

\begin{tabular}{ccccccccccccc}
\hline \multicolumn{10}{c}{} & \multicolumn{10}{c}{ Drill size (diameter: $\mathrm{mm}$ ) } \\
No. & Before & After & 0.52 & 0.54 & 0.56 & 0.58 & 0.60 & 0.65 & 0.70 & 0.75 & 0.80 \\
\hline & ++ & - & - & - & - & - & + & + & + & + & + \\
& ++ & - & - & - & - & - & + & + & + & + & + \\
5 & ++ & - & - & - & - & - & + & + & + & + & + \\
& ++ & - & - & - & - & + & + & + & + & + & + \\
& ++ & - & - & - & - & + & + & + & + & + & + \\
\hline
\end{tabular}

ナトリウムと $3 \%$ 過酸化水素水との交互洗浄では, $4 \mu \mathrm{m}$ までしか殺菌効果はなかったが, Er:YAGレーザーの $8 \mathrm{~mJ}$ 照射では, $18 \mu \mathrm{m}$ までの殺菌効果があることが判明 した（図 7)。この結果から,リーマーやファイルでの根 管拡大が難しい部位での根管拡大および殺菌の可能性が充 分あると考えられる。

3. 歯髄組織へのレーザー照射

1）露髄部へのレーザー照射

微小露䯣であれば出血も少なく, 細菌感染の可能性もの 少ない。しかし, 露出面積が大きい場合は出血が多く, 細 菌感染の可能性も高い。そこで, 露髄部に低出力でデ フォーカスの炭酸ガスレーザーを短時間照射することで, 薄い熱変性層を形成して止血を図るとともに，熱的殺菌を 目指すことも，レーザーの有効な治療法である。

2）レーザー照射による生活断髄

炭酸ガスレーザー光線を根管口に直接導光可能ならば, レーザーによる生活断髄も可能である。ただし, 照射の際 には，根管口周囲象牙質への蓄熱が生じることに注意が必 要である。何故なら, 過度の蓄熱が生じると, 熱の拡散に より残存歯䯣組織に対して持続的な熱刺激になり, 炎症を 引き起こすことになるからである。

3）根尖狭窄部付近へのレーザー照射

根尖狭窄部付近でのレーザー照射においては，図 8 に示
した 6 ケ所の部位に対して考慮を払わなければならない。

まず，根尖狭窄部よりやや歯冠側（1）では，歯䯣が 残っているのか, あるいは根尖孔外からの出血や排膿が見 られるのかによって，レーザー光の影響が根管内に留まる のか, 根尖孔外歯周組織まで影響を及ぼすのかが, 違って くる。

次に，考慮すべきなのは，根管内に挿入したレーザー照 射用チップ先端から出射されたレーザー光が，根管内象牙 質（2)）に影響を及ぼすのかについてである。レーザー照 射により象牙質が炭化などの熱的変性を起こしてしまう と, 通常のリーマーやファイルでのアピカルシート形成が 難しくなるとともに，根管充填材との接合も難しくなる。 更には，象牙質への過剩な蓄熱が歯根周囲歯周組織へ影響 を及ぼすことも考えられる。

同じ根管内象牙質ではあるが，セメント質象牙質境 (CDJ : cementum-dentin junction) は，尖っているので エネルギーが集中しやすい (3))。この CDJ を破壊してし まうと, アピカルシート形成や根管充填が非常に難しくな るので, 注意を払う必要がある。

根尖狭窄部を通過したレーザー光線は，歯根膜部に影響 を及ほすす（4)）。歯髄炎である場合は，ほぼ健全な歯根膜 組織のままなので，レーザー光線のコラーゲンに対する影 響を考虑する必要がある。一方，根尖性歯周炎の場合に 


\section{< Conclusion > Bactericidal effects to S.sanguis \\ Treatment \\ Mean depth $(\mu \mathrm{m})$}

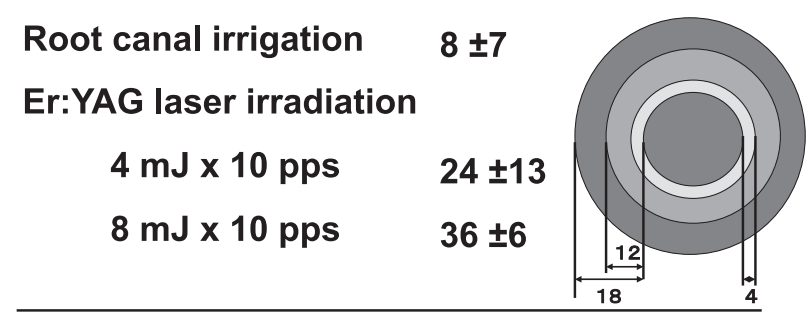

図 7 根管交互洗浄とレーザー照射の殺菌効果比較

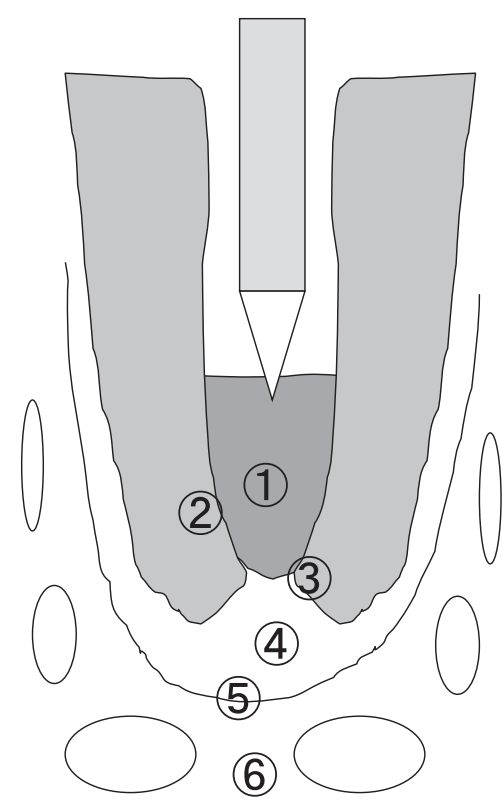

図 8 根尖狭窄部付近でのレーザー照射で注意すべき点

は, 根尖部は肉芽組織, 膿瘍あるいはのう胞など様々な様 態を示すので，用いるレーザーの作用を踏まえた注意が必 要である。

更には，組織透過性の高いレーザーでは影響が歯槽骨ま で及ぶことがあり，骨表面（5）や骨内部（6)）での変化 に対して考慮を払う必要がある。

つまり, 歯内治療でレーザーを用いる場合は, 出来るだ け根尖孔外周組織に影響を及ぼさないことが, 照射後の疼 痛や違和感を引き起こさないために重要である。

III. その他の臨床応用

1. 象牙質知覚過敏症

これまで多種類のレーザーが, 知覚過敏点・帯に直接, あるいは当該歯の根尖部歯肉に照射され，ある程度の臨床 的効果が報告されている。しかし, この効果のメカニズム が, 象牙細管内にある物質や象牙芽細胞の変性・変形によ るのか, あるいは歯髄内神経細胞あるいは根尖孔外の神経

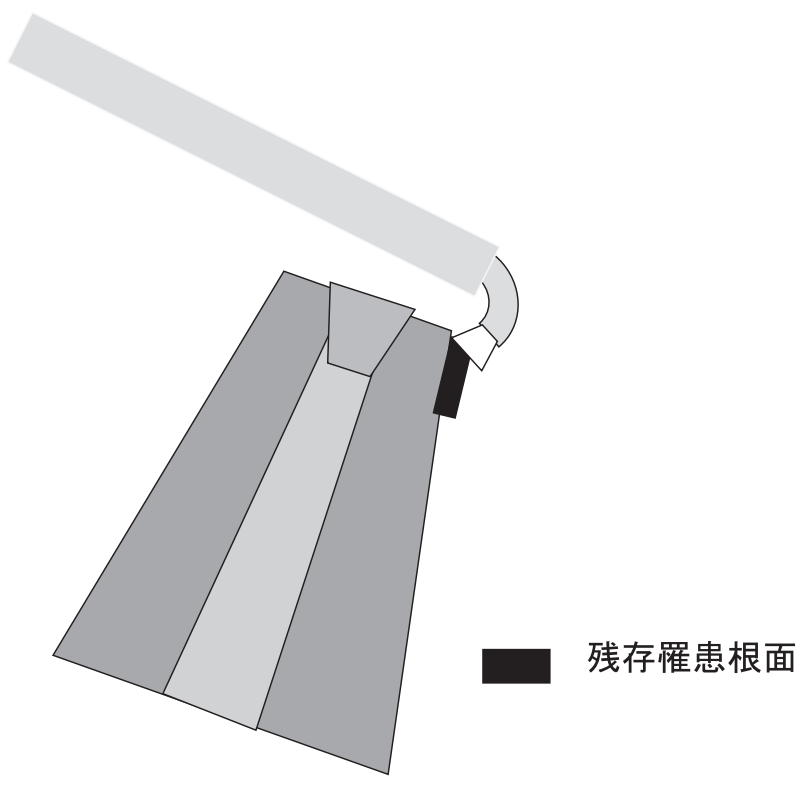

図 9 歯根端切除部へのレーザー照射

や血流への電磁的変化によるのかは明らかではなく，今後 の研究が待たれている。

2. 歯肉息肉除去

インプラントの二次手術での実績があるように，歯肉に 埋入している残根を露出させるのには，表層に炭化層が生 じるものの，無麻酔で無痛的に歯肉息肉や罹患象牙質（水 分が多く、コラーゲンも肥大しているのでレーザーを吸収 し易い）も除去できることから，一週間経過後の結果を考 えた場合，炭酸ガスレーザーが最も有効なレーザーだと思 われる。

3. 歯根吸収へのレーザー照射

通常のリーマーやファイルでは根管拡大が不可能な内部 吸収に対して, Er:YAG レーザーを側方に照射することで, 破歯細胞除去などの拡大が可能になる。

また, Er:YAGレーザーは, 軟組織と硬組織の両方に作 用するので, 外部吸収部の罹患象牙質と歯槽骨除去治療に も極めて有効である。

4. 歯根端部周囲の罹患象牙質除去（図 9）

歯根端切除を行った場合, 口蓋側や舌側など, 裏側に 残ってしまった罹患象牙質を除去することは通常の方法で は困難である。しかし，Er:YAGレーザーを側方照射型 チップで導光することで容易に除去が可能となり, 予後が より良いものとなる。

5. 樹脂系根管充填用シーラーの除去

最近, 象牙質との接着性が増した樹脂系根管充填用シー ラーが臨床に用いられるようになってきている。しかし, これらのシーラーは通常の溶剂に溶けないので, 器械的に 除去しなければならない。特に, 湾曲根管では除去が難し 


\section{<問題点 $>$}

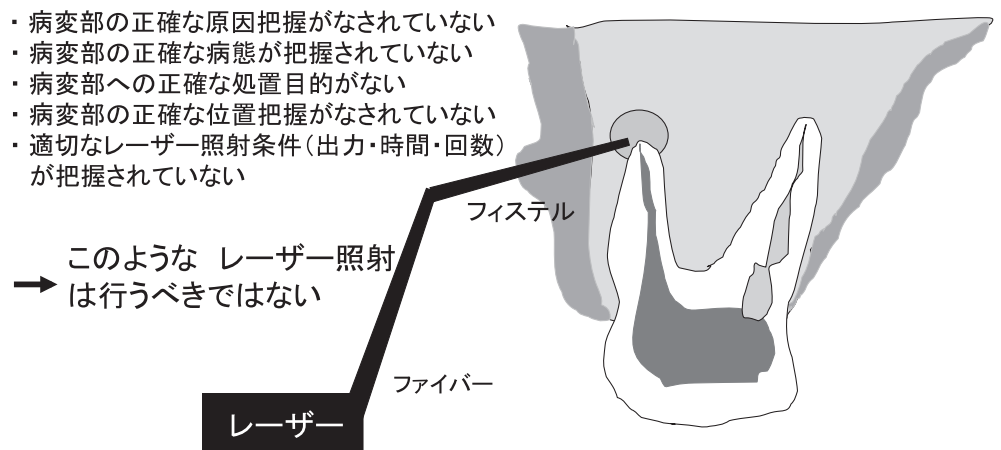

図 10 フィステル（ろう孔）からの不適切なレーザー照射

いので，側方照射用チップを用いれば，シーラーを除去で きる可能性が考えられるが，今後の研究が待たれる。

6. 根管側枝へのレーザー照射

電気的根管長測定器を用いた臨床での根管側枝検出を, 容易に行うことが可能になってきている。側枝への Er:YAG レーザー照射は，検出された側枝の傾きに合わせ てレーザーを照射すれば，これまで不可能であった側枝内 の根管拡大と殺菌が可能になる。このことは, これまで疼 痛の原因特定が困難であった歯の, 痛みの改善に繋がる可 能性は高いと筆者は考えている。

\section{まとめ}

根管という狭い治療域でのレーザー照射は, レーザーの 導光と照射方向という問題がある。しかも, レーザーの主 な作用である熱的作用が根尖部歯周組織まで波及した場 合, 痛みという点で大きな問題になる。このような問題は
あるものの，レーザーの歯内治療への応用は，これから発 展する可能性があり, 特に, 根尖部歯周組織での治癒促進 や痛み発現防止という面からも期待される治療手段と考え られる。

ただし，レーザー照射によって一時的に臨床症状（例： フィステル）が改善するからといって, 病因や原因歯・部 位を特定せずに，単にレーザーを照射する（図 10）こと だけは行うべきではない3）。

\section{文献}

1) Shoji S, Hariu H, Horiuchi H: Canal enlargement by Er:YAG laser using a cone-shaped irradiation tip, J Endodntics, 26 : 454-458, 2000.

2) 庄司茂, 満田隆之, 堀内 博: Er:YAGレーザーを用いた 抜髄後に, 即時根管充填を行った歯の根尖部歯周組織反応に 関する病理組織学的研究. 日歯内療誌, $23: 101-105,2002$.

3）庄司茂：レーザー照射によって生じた Hemosiderin を取り 込んだマクロファージが観られた症例. 日レ歯誌, 20 ： 9-13, 2009. 